\title{
Разработка и апробация хлоропластных праймеров для анализа гаплотипов хурмы коллекции ФИЦ СНЦ РАН
}

\author{
Рахмангулов Р.С.*, Симонян Т.А., Мацькив А.О., Цатурян Г.А., Шуркина Е.С., Омаров М.Д., \\ Кулян Р.В., Омарова 3.М. \\ Федеральное государственное бюджетное учреждение науки «Федеральный исследовательский центр \\ «Субтропический научный иентр Российской академии наук»», Россия \\ *e-mail: rakhmaruslan@yandex.ru
}

Ключевые слова: хлоропластные праймеры, Diospyros kaki, D. lotus, D. virginiana

Цель: Хурма является перспективной субтропической культурой для возделывания на Юге России. Несмотря на многочисленные молекулярно-генетические работы зарубежных исследователей, генетическое разнообразие и филогенетические взаимосвязи российской коллекции сортов хурмы до сих пор не изучены.

Meтоды: Объектами исследования послужили генотипы хурмы из коллекций ФИЦ СНЦ РАН, среди которых сорта Diospyros kaki, виды хурмы D. lotus и D. virginiana. ДНК выделяли из вызревших листьев хурмы методом ЦТАБ [1]. Анализировали качество выделенной ДНК с помощью электрофореза в 1,5\% агарозном геле; концентрацию ДНК измеряли на спектрофотометре BioDrop microlite. Анализ генетического разнообразия хурмы проводили с помощью 9 хлоропластные маркеров на основе секвенированного хлоропластного генома [2]. Объем реакционной смеси 25 мкл, из которых 12,5 мкл двухкратный ПЦР буфер (Биолабмикс) содержащий Таq-ДНК-полимеразу горячего старта. ПЦР смесь содержала 0.5 мкл маркера (10 мкмоль), 1 мкл ДНК ( 66,6 мкг/мл) и деионизированную воду. Амплификацию проводили по следующей программе: преинкубация 5 мин при $95{ }^{\circ} \mathrm{C}$, денатурация 15 сек при $95{ }^{\circ} \mathrm{C}$, отжиг 40 циклов по 40 сек при $60{ }^{\circ} \mathrm{C}$, с последующей финальной элонгацией 5 мин при $72{ }^{\circ} \mathrm{C}$. Продукты ПЦР визуализировали в $1.5 \%$ агарозном геле с $1 \times \mathrm{TAE}$ буфером при напряжении $90 \mathrm{~V}$. Анализ генетических дистанций проводили методом Neighbor Joining c коэффициентами попарного сходства по L.R. Dice [3]. Построение дендрограммы филогенетических дистанций исследуемых сортов хурмы проводилось с помощью пакета программ Darwin.

Pезультаты: На основе секвенированного хлоропластного генома, было разработано 9 хлоропластных маркеров. Из разработанных 9 маркеров 4 разработаны на основе, D. lotus и 5 на основе D. kaki. К этим маркерам были разработаны праймеры с температурой отжига не менее $60{ }^{\circ} \mathrm{C}$ и соотношением GC пар в соотношении 47-53\%. С помощью данных праймеров были получены амплифицированные фрагменты размером 176-250 пн. Разработанные праймеры показали высокую эффективность для выявления различий между образцами хурмы в коллекции ФИЦ СНЦ РАН.

Заключение: В результате хлоропластного анализа выявлено три основных гаплотипа, из которых один уникальный гаплотип. Эти данные послужат основой для целенаправленной селекции хурмы и увеличения генетического разнообразия коллекций хурмы.

\section{Список литературы}

1. Doyle J.J., Doyle J.L. A rapid DNA isolation procedure for small quantities of fresh leaf tissue. Phytochemical Bulletin, 1987;19:11-15.

2. Fu J., Liu H., Hu J., Liang Y., Liang J., Wuyun T., Xioafeng T. Five complete chloroplast genome sequences from Diospyros: genome organization and comparative analysis. PlosOne. 2016.11(7): e0159566.doi:10.1371/journal.pone.0159566.

3. Dice L.R. Measures of the amount of ecologic association between species. Ecol. 1945;.26:297302.dx.doi.org/10.2307/1932409. 